\title{
Analysis of percolation and seepage through paddy bunds
}

\author{
Han-Chen Huang ${ }^{a}$, Chen-Wuing Liu ${ }^{a}$,*, Shih-Kai Chen ${ }^{b}$, Jui-Sheng Chen ${ }^{c}$ \\ ${ }^{a}$ Department of Bioenvironmental Systems Engineering, National Taiwan University, Taipei 106, Taiwan, ROC \\ ${ }^{\mathrm{b}}$ Chi-Sheng Water Management Research and Development Foundation, Taipei 106, Taiwan, ROC \\ ${ }^{\mathrm{c}}$ Department of Environmental Engineering and Sanitation, Foo-Yin University, Kaohsiung 831, Taiwan, ROC
}

Received 22 October 2002; revised 19 May 2003; accepted 27 May 2003

\begin{abstract}
This study investigates percolation and seepage through the bunds of flat and terraced paddies. Field experiments were conducted in Hsin-Pu of Hsin-Chu County, Taiwan, to measure the soil water content of various types of bund. Measurements revealed that the soil was unsaturated along the sloped surface of the terrace. Experimental results also indicated that seepage face flow did not develop even after 2 days of heavy rainfall. A three-dimensional model, FEMWATER, was adopted to simulate percolation and lateral seepage under various bund conditions. In a flat paddy, the rate of percolation of bunds under which a plow sole was located, was $0.40 \mathrm{~cm} \mathrm{~d}^{-1}$, close to the average infiltration rate of a flooded paddy. The percolation of the bund without plow sole was $0.85 \mathrm{~cm} \mathrm{~d}^{-1}$, or double the average infiltration rate of a flooded paddy. Infiltration in the central area of a terraced paddy is mainly vertically downward, whereas flow near the bund is predominantly lateral. The paddy field near the bund has a high hydraulic gradient. The simulated infiltration flux into the bund $\left(1.47 \mathrm{~cm} \mathrm{~d} \mathrm{~d}^{-1}\right)$ after 85 days of rice cultivation exceeded that into the central area $\left(0.54 \mathrm{~cm} \mathrm{~d}^{-1}\right)$ by a factor of 2.72 . The final percolation flux from the bund $\left(1.24 \mathrm{~cm} \mathrm{~d}^{-1}\right)$ also exceeded the final percolation from the plow sole $\left(0.68 \mathrm{~cm} \mathrm{~d}^{-1}\right)$ by a factor of 1.82 . The lateral seepage fluxes through the bund, downward and upward along the slope surface, are 2.01 and $-2.12 \mathrm{~cm} \mathrm{~d}^{-1}$, respectively. However, the lateral seepage flux does not fully saturate the surface of the hillside soil. A simulation clearly shows that the seepage upstream of the paddy field does not move water downstream and is reused as subsurface return flow. Both experimental and simulation results clarify the mechanisms of water movement in the terraced paddy and reveal the existence of an unsaturated seepage face along the sloping surface of the terraced field.
\end{abstract}

(C) 2003 Elsevier B.V. All rights reserved.

Keywords: Bund; Terrace; Seepage; Percolation

\section{Introduction}

Irrigation efficiency is of paramount importance in flooded rice cultivation. Efficiency relates the amount of water used by the plant to the amount of water

\footnotetext{
* Corresponding author. Tel.: + 886-2-2362-6480; fax: + 886-22363-9557.

E-mail address: lcw@gwater.agec.ntu.edu.tw (C.-W. Liu).
}

extracted from the water source; it measures the amount of water lost from the system.

A water balance equation determines the efficiency of water usage in a paddy field

$$
I+R=E+T+S+P+D+\mathrm{d} W
$$

where $I$, irrigation supply, $R$, rainfall, $E$, evaporation, $T$, transpiration, $S$, lateral seepage, $P$, percolation, $D$, 
surface drainage or runoff, and $\mathrm{d} W$, change in flooded water depth and, equivalently, the amount of water stored in the soil, all expressed in $\mathrm{cm} \mathrm{d}^{-1}$. Percolation, included in Eq. (1), represents the rate of the vertical movement of water beyond the root zone to the water table, while lateral seepage represents the rate of the movement of subsurface water between fields. The infiltration equals the summation of the lateral seepage and the percolation. Since flooded paddy rice fields perform many functions, such as ecological and environmental conservation, as well as rice production, losses due to percolation and seepage from a flooded rice paddy can be regarded as sources of groundwater recharge and should not be considered to be irrigation losses in current water resource management.

In field studies of percolation, vertical losses through a plow layer can be measured using various infiltrometer and lysimeter techniques. However, to our knowledge, no techniques for directly measuring horizontal losses into bunds have been established. Horizontal flow from one field has generally been thought to represent a gain of the adjacent field, such that the system experiences no net loss. However, water balance and ponding tests indicate that a balance cannot be achieved if evapotranspiration (ET), surface drainage and percolation through the plow layer are taken to be the only sources of loss (Walker and Rushton, 1984; Bouman et al., 1994; Tuong et al., 1994; Wopereis et al., 1994). The bund is the only other possible source of loss. In some cases, the bund is not disturbed from year to year, and the plough layer forms an increasingly impermeable base, or plow sole, in the rice field. If the plow sole does not extend through the bund, the irrigation water can pass through the bund down into the underlying water table. In other cases, if the old, irregularly shaped rice paddy has been changed to a standardized rotational irrigation paddy to increase the efficiency of irrigation, then a plow sole may be present on the bottom of the new bund in the converted paddy such that the irrigation water can only move horizontally through the bund. The lateral seepage flow field in the former case is of the downward flow type; in the latter case, it is of the horizontal flow type. Fig. 1 schematically depicts these two types of lateral seepage through the bunds.
Walker and Rushton (1984) applied the downward flow type model to examine numerically the mechanism and magnitude of flow through the bund and in the underlying aquifer. They showed that lateral seepage could be greatly reduced by maintaining shallow depths of water in a flat paddy rice field. However, they did not investigate the horizontal flow type of seepage, which may be important in terraced paddy rice fields, where seepage through bunds is typically considered to be an important source of irrigation water for the adjacent downstream terraced paddy. This type of lateral seepage, sometimes called subsurface return flow, may increase the efficiency of the use of irrigation water in the terraced paddy (Huang et al., 2001).

This study examines percolation and lateral seepage of both horizontal and downward flow types in the vicinity of the bund. Soil water content around the paddy bund is experimentally determined. Water infiltration in flat paddies and terraced paddies is simulated using the numerical model, FEMWATER (Lin et al., 1997). Numerical results are compared with field observations. The flow field of irrigation water is determined to illustrate the processes of percolation and lateral seepage through flat and terraced paddy bunds.

\section{Materials and methods}

\subsection{Field experiments}

\subsubsection{Bund types}

Five types of bund are common in the paddy fields of Taiwan. They are the soil bund, the concrete bund, the gravel-packed bund, the concrete-covered soil bund and the plastic-covered soil bund. The soil bund is made of native soil. The bund is $25-30 \mathrm{~cm}$ high and $30-50 \mathrm{~cm}$ wide. When the bund is in contact with ponded water over a long period, the bund's soil may become loose, slippery and hard to maintain. A concrete bund is built directly from premixed concrete slurry. The concrete bund is durable, easy to maintain and allows practically no water seepage. It is higher and narrower than the soil bund. The gravel-packed bund is primarily used in terraced paddies. An impermeable clay layer is first smeared homogeneously on the surface of the slope to reduce the seepage of floodwater through the bund. 


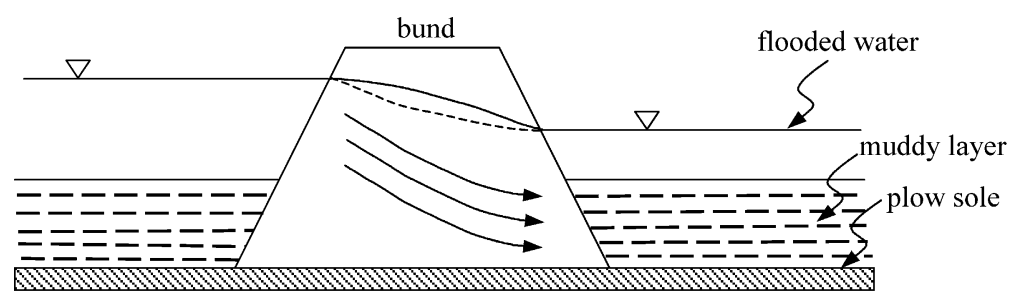

unsaturate zone

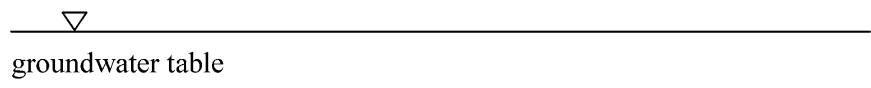

(a) Horizontal flow type

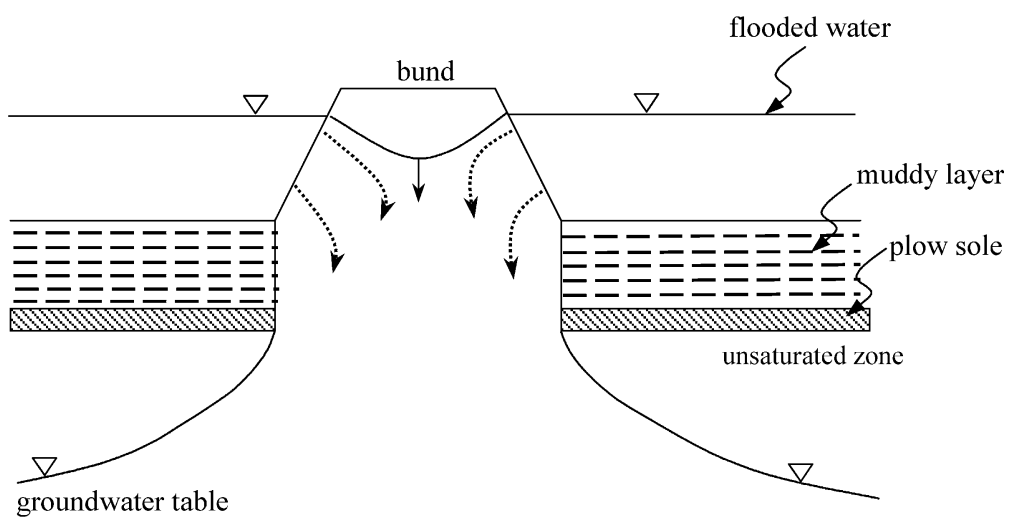

(b) Downward flow type

Fig. 1. Two types of lateral seepage flow through bunds (not to scale).

Similarly sized gravels are then packed on top of the clay layer on the slope surface. The gravel-packed bund is less durable than the first two types of bund. With large volumes of runoff water, the gravel packed bund is likely to break. The concrete-covered soil bund is typically built along a drainage channel to protect the bund's inside wall. The plastic-covered soil bund prevents irrigation water from seeping through and softening the soil. Over $80 \%$ of all bunds in paddy fields in Taiwan are soil and concrete bunds.

\subsubsection{Hydraulic characteristics of bunds}

The hydraulic conductivity of the soil underneath a bund determines whether the lateral seepage flow field is of the downward or horizontal type. If the plow sole extends to the bottom of the bund, then the seepage is horizontal; otherwise it is downward. Eight soil samples were collected at $15 \mathrm{~cm}$ intervals from the top surface of the bund $(-15 \mathrm{~cm})$ to a depth of $105 \mathrm{~cm}$. The samples were collected at four bund sites at the Chi-Tung flat paddy field of Yun-Lin. Their hydraulic conductivity was measured. The downward direction was the positive direction such that the top surface of the soil bund is at $-15 \mathrm{~cm}$. The sample cylinders were $15 \mathrm{~cm}$ long and $12.7 \mathrm{~cm}$ in diameter. The saturated hydraulic conductivities of subsoil samples were measured by the falling head method (Klute and Dirksen, 1986).

A $5-10 \mathrm{~cm}$ thick plow sole was usually located $20 \mathrm{~cm}$ below a paddy surface. The average hydraulic conductivity of the plow sole was $0.05 \mathrm{~cm} \mathrm{~d}^{-1}$ (Chen and Liu, 2002), 20-30 times less than that of non-puddled subsoil layers (Wopereis 
Table 1

Saturated hydraulic conductivity $\left(\mathrm{cm} \mathrm{d}^{-1}\right)$ of soils at various depths (cm) below paddy bunds at Chi-Tung

\begin{tabular}{llccc}
\hline Depth & Bund 1 & Bund 2 & Bund 3 & Bund 4 \\
\hline-15 to 0 & 2.72 & 0.59 & 0.45 & 1.37 \\
$0-15$ & 3.09 & 0.25 & 0.08 & 0.29 \\
$15-30$ & 1.65 & 1.46 & 0.39 & 0.25 \\
$30-45$ & 0.36 & 0.05 & 0.02 & 0.25 \\
$45-60$ & 0.49 & 1.46 & 0.18 & 0.32 \\
$60-75$ & 0.97 & 1.24 & 0.21 & 0.86 \\
$75-90$ & 3.92 & 11.98 & 1.54 & 7.27 \\
$90-105$ & 1.74 & 20.04 & 11.91 & 1.72 \\
\hline
\end{tabular}

et al., 1992, 1994). Table 1 presents the hydraulic conductivities at various depths. Comparing the subsoil's hydraulic conductivities $(K)$ at a depth of $30-45 \mathrm{~cm}$ for the four bunds, yielded $K$ values at bunds 2 and 3 of 0.047 and $0.0158 \mathrm{~cm} \mathrm{~d}^{-1}$, respectively, at least one order of magnitude smaller than those at bunds 1 and 4 . The $K$ values at bunds 2 and 3 also fall within the range of the plow sole. The Chi-Tung paddy was converted from an irregular, old paddy into a new rotational irrigation paddy in 1980. The new rotational irrigation paddy is standardized and includes four irrigation units with a total area of 48 ha. After the reconstruction, some of the original bunds were removed and new bunds were built on top of the paddy field. The old, unremoved bunds (bunds 1 and 4) maintained their relatively high hydraulic conductivity at the position of the plow sole layers. The plow sole layers with low hydraulic conductivity extended though the newly constructed bunds (bunds 2 and 3).

\subsubsection{Soil water saturation}

The distribution of soil water saturation inside the bund generally depends on the type of bund. The concrete bund is much less permeable than the soil bund and so water saturation in the former is less than in the latter. Walker and Rushton (1984) simulated the free surface position of the soil bund of the downward flow type in a flat paddy. Water enters the bund from the rice fields and initially forms a convex upward surface that quickly becomes concave, which shape it retains. The permeability of the soil bund determines the curvature of the concave downward free surface. However, the distribution of soil water saturation in a terraced paddy may differ from that in a flat paddy. Field observations indicate that the exterior surface of the slope of the bund is commonly dry, and, usually, no water seepage occurs in the terraced paddy. The soil water saturation in the terrace may be less than in the flat paddy. Field measurements of soil water saturation were taken in the terrace paddy fields of Hsin-Chu county, using a portable EC-200 multimeter in the vicinity of three types of bunds soil, gravel-packed and concrete. A multimeter was used to measure the percentage of soil water saturation at different depths along the terraced bunds. Fig. 2 schematically depicts the soil

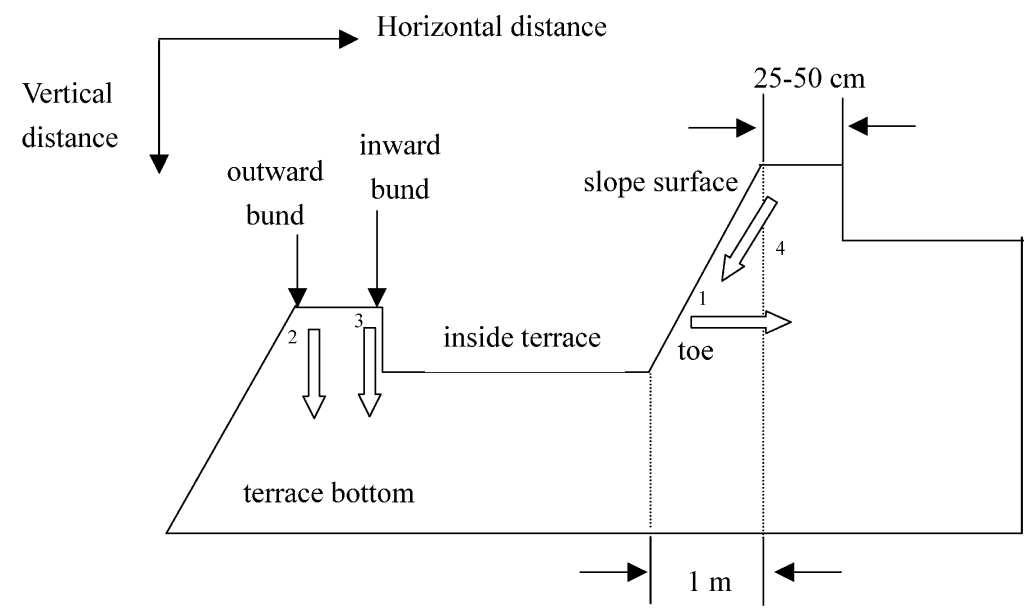

Fig. 2. Schematic representation of a cross-sectional view of terraced rice field and the terminology used herein. Open arrows indicate soil water sampling locations and directions (not to scale). 
water sampling locations and the directions of the terraced paddies.

\subsection{Numerical model}

\subsubsection{Flat paddy model}

Although Taiwan's paddy fields use various types of bunds, soil and concrete bunds are the two most prevalent types. The soil bund is the most common, and has the advantage of convenient construction; however, it is difficult to maintain. The concrete bund provides the advantages of durability and low seepage, and has gradually replaced the soil bund. Soil bunds are now being restored in Taiwan's paddy field because of the many benefits of environmental and ecological conservation. The three-dimensional (3D) model, FEMWATER (Lin et al., 1997) was used in GSM environments (Engineering Computer Graphic Laboratory, 1996) to simulate percolation and lateral seepage, to analyze the processes around soil bunds under flood paddy conditions. A basic bund model, shown in Fig. 3, was used, $30 \mathrm{~cm}$ wide by $30 \mathrm{~cm}$ high. The simulated area was $100 \mathrm{~m} \times 50 \mathrm{~m}$ and the vertical depth was $11 \mathrm{~m}$. The plow sole was covered with a $20 \mathrm{~cm}$ muddy layer; the plow sole layer was $7.5 \mathrm{~cm}$ thick and had a hydraulic conductivity of $0.05 \mathrm{~cm} \mathrm{~d}^{-1}$. Below the plow sole was a $32.5 \mathrm{~cm}$ silt layer with a hydraulic conductivity of $1.1 \mathrm{~cm} \mathrm{~d}^{-1}$. Beneath the silt layer was a $7.4 \mathrm{~m}$ red loam layer with a hydraulic conductivity of $1.6 \mathrm{~cm} \mathrm{~d}^{-1}$ and a $0.2 \mathrm{~m}$ back clayey loam layer with a hydraulic conductivity of $1.5 \mathrm{~cm} \mathrm{~d}^{-1}$. The bottom zone was an unconfined aquifer that was comprised of

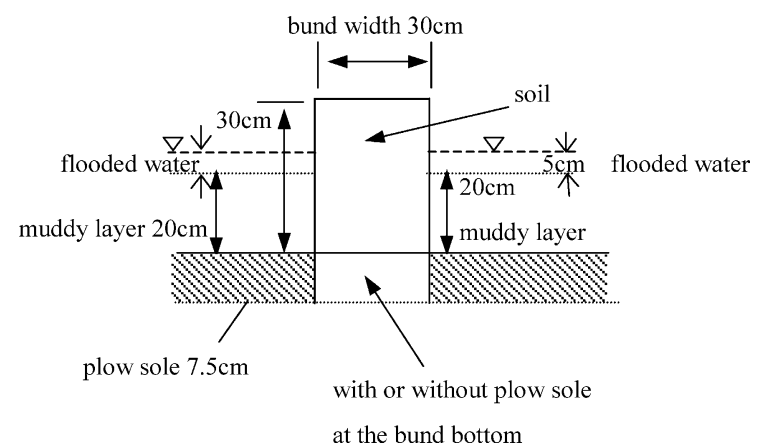

Fig. 3. Cross-section in the vicinity of the bund of a typical flooded rice field (not to scale). large gravels and variously sized cobbles. This zone was highly permeable and had a hydraulic conductivity of $300 \mathrm{~cm} \mathrm{~d}^{-1}$ (Chen and Liu, 2002). The depth of the groundwater was $10 \mathrm{~m}$ below the surface and the floodwater was $5 \mathrm{~cm}$ deep, under constant head boundary conditions. Scenarios in which the plow sole was extended and in which it was not extended to the bottom of the soil bund were simulated.

The saturated hydraulic conductivity of the soil bund was set to $1.1 \mathrm{~cm} \mathrm{~d}^{-1}$. Percolation and seepage occur with and without a plow sole under the bunds. If the plow sole does not extend to the bottom of the bunds, then a silt layer, with a saturated hydraulic conductivity of $1.1 \mathrm{~cm} \mathrm{~d}^{-1}$, replaces it at the bottom of the bunds. The initial pressure head of the soil in flooded paddy fields is set to $-1.2 \mathrm{~m}$ (Chen and Liu, 2002). Simulations were run for 30 days to reach steady state conditions.

\subsubsection{Terraced paddy model}

The most popular bund in a terraced paddy is the soil bund, because it is simple and inexpensive to construct. A two-level terraced paddy with a soil bund, as shown in Fig. 4, was conceived. Each level had an area of $10 \mathrm{~m} \times 10 \mathrm{~m}$ with a bund width and height of $50 \mathrm{~cm}$ and $20 \mathrm{~cm}$. The slope of the terrace was at $60^{\circ}$ and the vertical distance between the upper and lower terraced paddy was $2 \mathrm{~m}$. The ET boundary condition (BC) of ET $=0.3 \mathrm{~cm} \mathrm{~d}^{-1}$ was applied to the surface of the slope. Due to topographic constraints, no plow sole is generally found underneath a soil bund. The plow sole is thus only $20 \mathrm{~cm}$ below the paddy surface, and is $7.5 \mathrm{~cm}$ thick; it does not extend to the bottom of the bund. Below it is a $4 \mathrm{~m}$ loam layer and at the very bottom is a $10 \mathrm{~m}$ thick gravel layer. The groundwater table is $4.5 \mathrm{~m}$ below the surface, and is located at the boundary between the loam and gravel layers. The saturated hydraulic conductivity of the plow sole, loam and gravel is $0.05,3.0$ and $300 \mathrm{~cm} \mathrm{~d}^{-1}$, respectively. The initial pressure head is $-3.3 \mathrm{~m}$ for all soils. The simulation is run for 85 days, to include a complete rice-growing cycle after transplantation; the depth of the floodwater is maintained at $5 \mathrm{~cm}$ for the first 60 days, and drainage conditions pertain over the last 25 days. The simulated results are analyzed to determine the overall infiltration, 


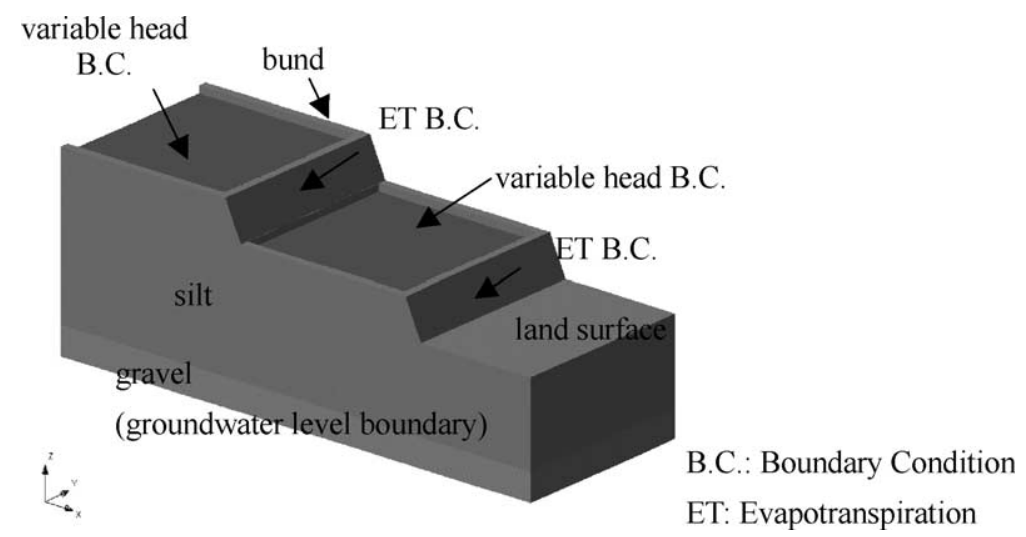

Fig. 4. Model of terraced rice paddy (not to scale).

the percolation and the lateral seepage in a terraced paddy.

\section{Results and discussion}

\subsection{Field measurements}

Fig. 5 shows the water saturation measurements at various locations and in various directions, take adjacent to the soil, the gravel-packed and the concrete bunds in the terraced field. The soil bund was $25-50 \mathrm{~cm}$ wide, and had a vertical height of $1.5 \mathrm{~m}$ and a bottom width of $1 \mathrm{~m}$, forming a $63.4^{\circ}$ sloping surface. The water saturation in direction 1 (Fig. 2), initially declined and then gradually increased toward the inside of the terraced paddy, ranging from 78 to $85 \%$ (Fig. 5(a)). The high water saturation at the slope surface resulted from 2 days of rain immediately before measurements were taken. The water content increased horizontally toward the inside of the paddy because of infiltration from the upstream field. Although water saturations were high, all measurements showed partial saturation. Water saturations measured in direction 3 generally exceeded those measured in direction 2 , because the floodwater moved from inside the terrace to the inward bund, and then to the outward bund (Fig. 3(b)). The high water saturation at a depth of $40 \mathrm{~cm}$ measured in direction 2 was attributed to the retardation of the infiltrating water by the plow sole, and the subsequent increase in saturation.
The gravel-packed bund was covered with a $10 \mathrm{~cm}$ thick layer of gravel; it was $25 \mathrm{~cm}$ wide, $2 \mathrm{~m}$ high, with a $30 \mathrm{~cm}$ bottom width and an $87.1^{\circ}$ sloping surface. The water saturations measured in direction 4 showed that no saturated seepage face developed along the gravel-packed slope surface (Fig. 5(c)). Other measurements taken in directions 2 and 3 of the gravel packed bund indicated that the inward bund water saturation exceeded the outward bund water saturation, and that both inward and outward bund measurements varied only slightly (Fig. 5(d)).

Fig. 5(e) compares the water saturations measured in direction 3 of the soil and gravel-packed bunds. The patterns of saturation are similar to the distribution of soil water in the flat paddy field, regardless of the type of bund (Chen and Liu, 2002). The soil water saturates at depths from 0 to 20 in the muddy layer, $>90 \%$ saturation is observed at a depth of $20-40 \mathrm{~cm}$, corresponding to the position of the plow sole, and $<90 \%$ is observed below a depth of $40 \mathrm{~cm}$.

The measurements of water saturation along the three types of bunds in direction 2 in the terraced paddy showed all revealed partial saturation (Fig. 5(f)). The concrete bund was close to full saturation, because water accumulated along the low, permeable concrete bund. Accordingly, the lateral seepage through these bunds is of the downward flow type, rather than the horizontal flow type. Notably, no saturated seepage faces developed along the slope surface of any of the three types of bund in the terraced paddies. 


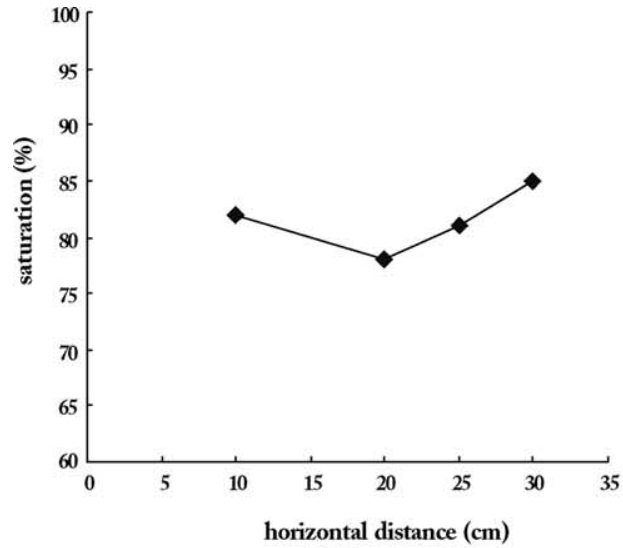

(a)

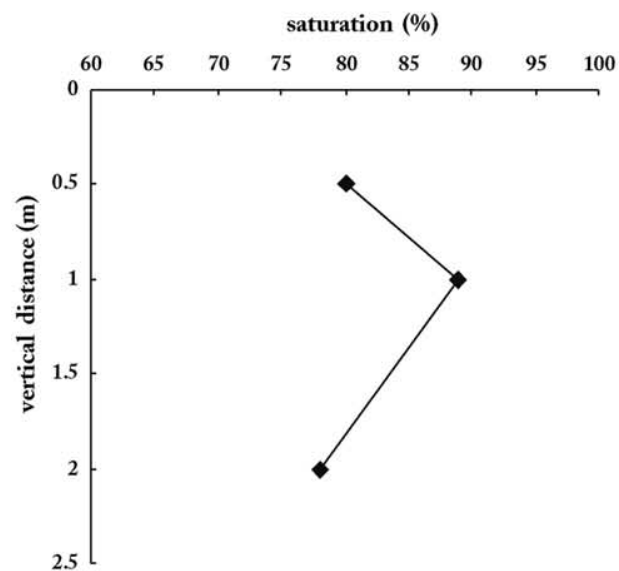

(c)

saturation (\%)

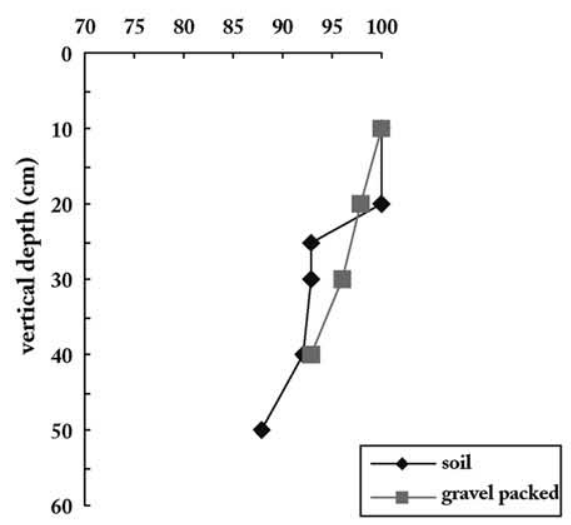

(e)

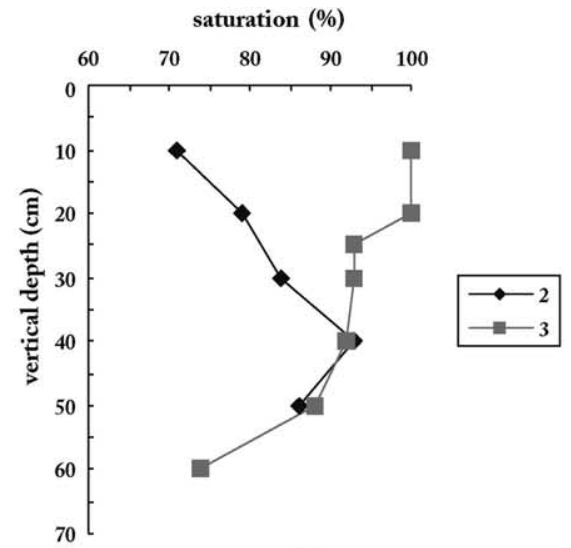

(b)

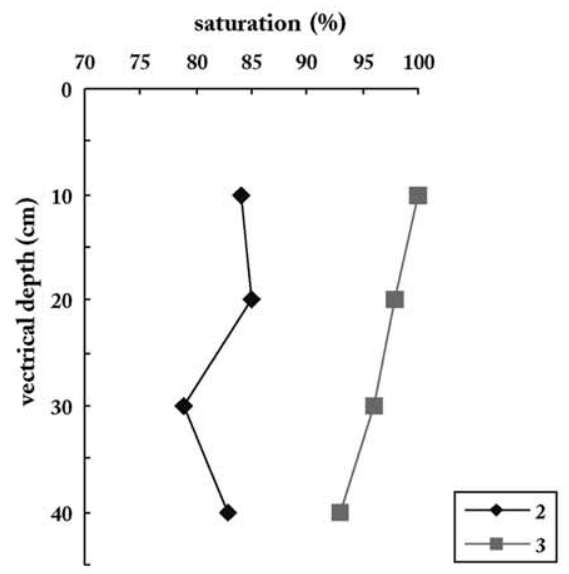

(d)

saturation (\%)

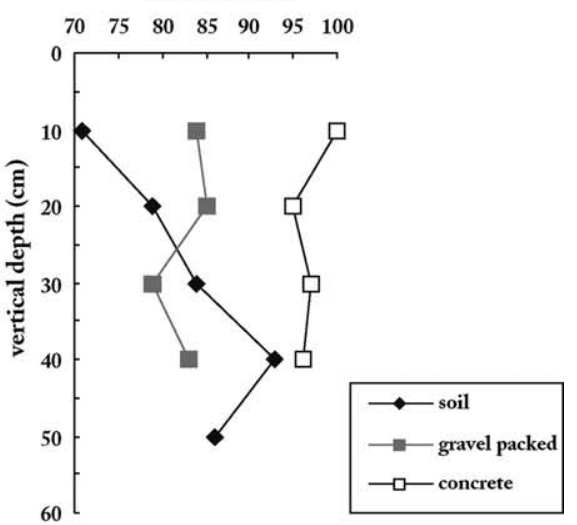

(f)

Fig. 5. Comparison of water saturation in soil, gravel-packed and concrete bunds in terraced rice paddy fields; (a) soil bund in direction 1; (b) soil bund in directions 2 and 3; (c) gravel-packed bund in direction 4 (d) gravel-packed bund in directions 2 and 3; (e) in direction 3; (f) in direction 2 . 
upward flow line indicates the soil

bund under moisture suction condition

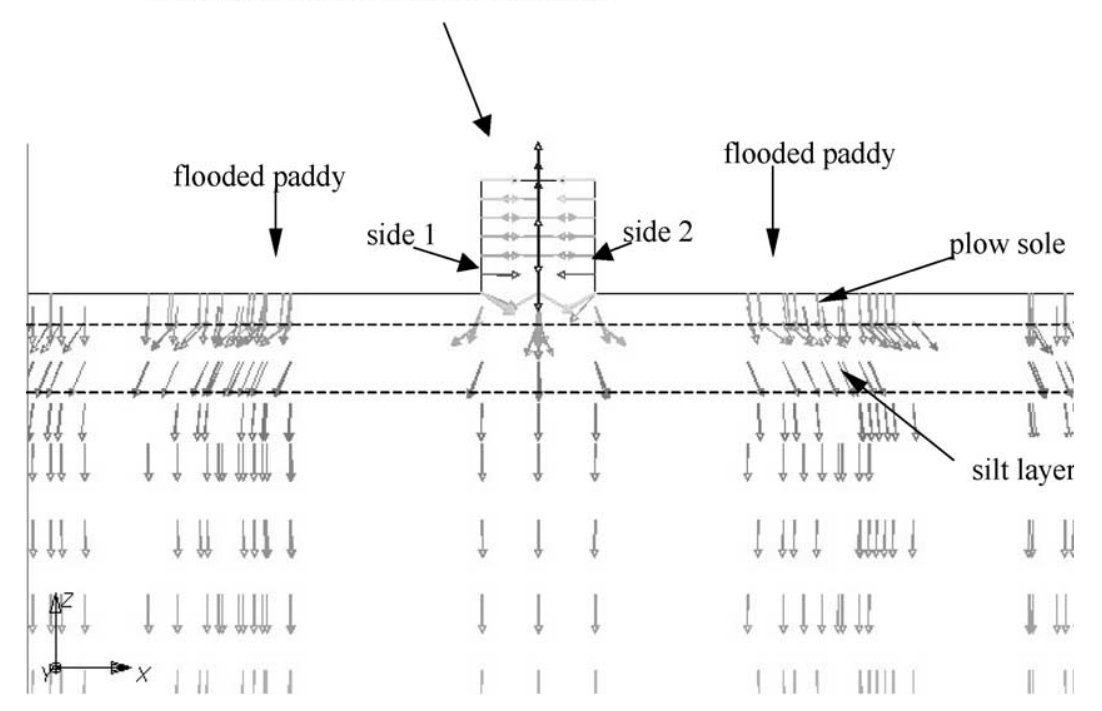

Fig. 6. Simulated Darcy velocity field of soil bund in a flooded paddy.

\subsection{Flat paddy}

Fig. 6 plots the simulated flow line distribution for a soil bund under the conditions described in Fig. 3, with a plow sole underneath. Water homogeneously moves from both sides of the flooded paddy to the soil bund. The upward water movement implies that the soil bund is unsaturated. The simulated steady state results provide useful data for quantifying lateral seepage and percolation. The average lateral seepage through sides 1 and 2 of the soil bund, with a plow sole underneath, is $0.33 \mathrm{~cm} \mathrm{~d}^{-1}$, whereas the percolation rate underneath the bund is $0.40 \mathrm{~cm} \mathrm{~d}^{-1}$, whose value is similar to the average water infiltration rate in a flooded paddy (Chen et al., 2002). The lateral seepage rate through the bund is approximately 0.8 times the percolation rate from the bottom of the bund.

If the soil bund has no plow sole underneath, then the average lateral seepage through sides 1 and 2 is $0.45 \mathrm{~cm} \mathrm{~d}^{-1}$, and the percolation rate underneath the bund becomes $0.85 \mathrm{~cm} \mathrm{~d}^{-1}$. The lateral seepage rate through the bund is about half of the percolation rate from the bottom of the bund, which is double the average water infiltration rate in a flooded paddy. Chen and Liu (2002) determined that the average infiltration rate is
$1.30 \mathrm{~cm} \mathrm{~d}^{-1}$, by breaking the plow sole in the rice paddy of an experimental field in Ten-Chung. The percolation rate of $1.30 \mathrm{~cm} \mathrm{~d}^{-1}$ is 1.5 times higher than the percolation rate $\left(0.85 \mathrm{~cm} \mathrm{~d}^{-1}\right)$ in the bottom of the bund with no plow sole underneath. The difference of $0.45 \mathrm{~cm} \mathrm{~d}^{-1}$ is redistributed as lateral seepage through the bund. Moreover, the sum of the percolation and lateral seepage rates underneath the bund with no plow sole equals $1.30 \mathrm{~cm} \mathrm{~d}^{-1}$, which is the same as the infiltration rate measured at Ten-Chung after the plow sole in the flooded paddy field was broken. The simulated result closely agrees with the field measurement, indicating that the numerical model satisfactorily represents the paddy field conditions. Although two patterns of flow through bunds were depicted (Fig. 1), the simulated results did not follow this classification but exhibited a mixed type flow pattern. The simulated seepage and percolation rates through the bottom of the bund, are 0.33 and 0.40 , respectively, with the plow sole underneath and 0.45 and $0.85 \mathrm{~cm} \mathrm{~d}^{-1}$ without. The ratios of the lateral seepage rate to the percolation rate are 0.8 and 0.5 , respectively, suggesting that percolation dominates the lateral seepage, regardless of the presence of a plow sole underneath the bund. 


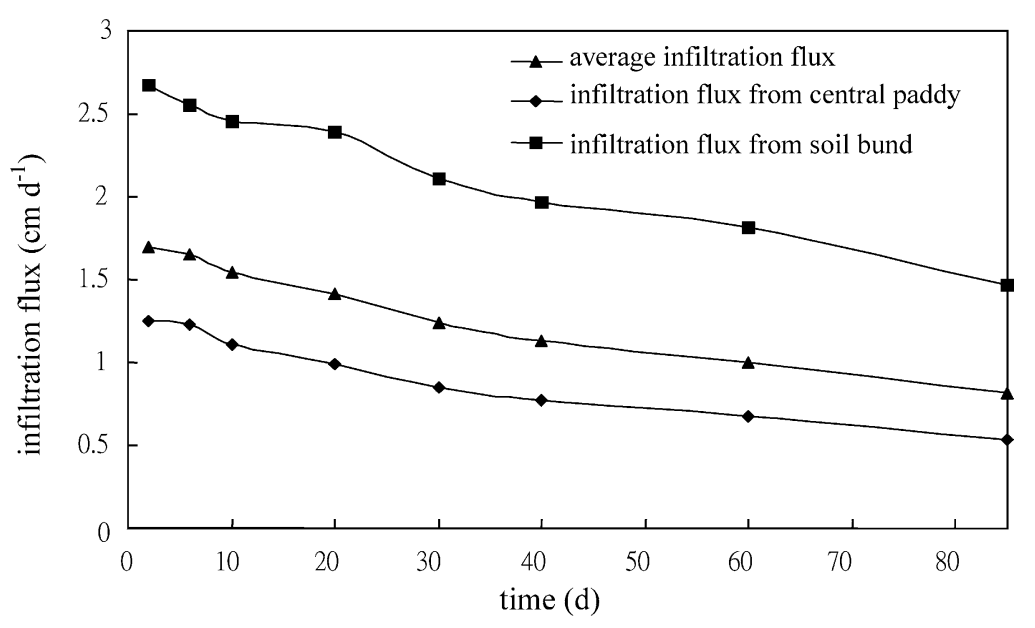

Fig. 7. Infiltration fluxes in the upstream terraced paddy.

\subsection{Terraced paddy}

The simulated infiltrations in the soil bund with no plow sole underneath, indicate that the initial infiltration flux is $1.69 \mathrm{~cm} \mathrm{~d}^{-1}$. This value measured the rate of water infiltration through the bottom of the muddy layer and is an areal average of the infiltration flux of $1.25 \mathrm{~cm} \mathrm{~d}^{-1}$ from the central terraced paddy, and that of $2.67 \mathrm{~cm} \mathrm{~d}^{-1}$ below the soil bund (Fig. 7). The initial infiltration flux below the soil bund with no plow sole underneath, is 2.13 times higher than that in the central terraced paddy, from which it differs by $1.42 \mathrm{~cm} \mathrm{~d}^{-1}$. After 60 days of simulation, the flooded water begins to drain slowly and the infiltration flux decreases accordingly. After 85 days, the average final infiltration flux falls to $0.81 \mathrm{~cm} \mathrm{~d}^{-1}$, and the final infiltration flux in the central terraced paddy drops to $0.54 \mathrm{~cm} \mathrm{~d}^{-1}$. However, the final infiltration flux below the soil bund drops to only $1.47 \mathrm{~cm} \mathrm{~d}^{-1}$, mainly because no plow sole is under the bund. The difference between the final infiltration in the central paddy and that in the region below the soil bund is $0.93 \mathrm{~cm} \mathrm{~d}^{-1}$, or a factor of 2.72. The total amount of infiltrated water after 85 days from a $10 \mathrm{~m} \times 10 \mathrm{~m}$ terraced paddy is $58 \mathrm{~m}^{3}, 46 \mathrm{~m}^{3}$ of which infiltrates from the central paddy and $12 \mathrm{~m}^{3}$ from the soil bunds. The amount of water that infiltrates from the soil bund represents $21 \%$ of the total amount that infiltrates from the terraced

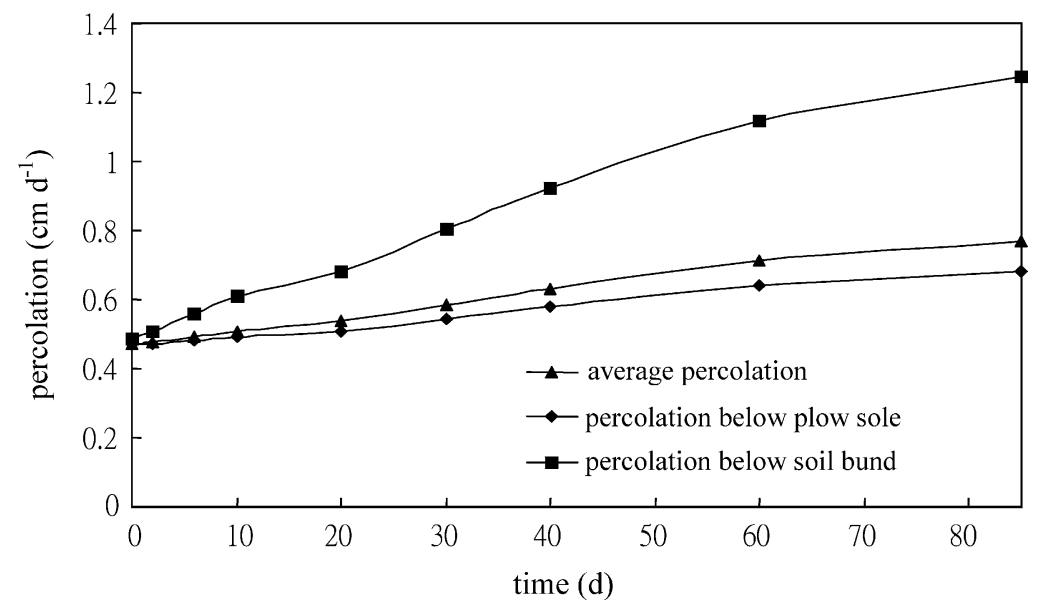

Fig. 8. Percolation in the upstream terraced paddy. 


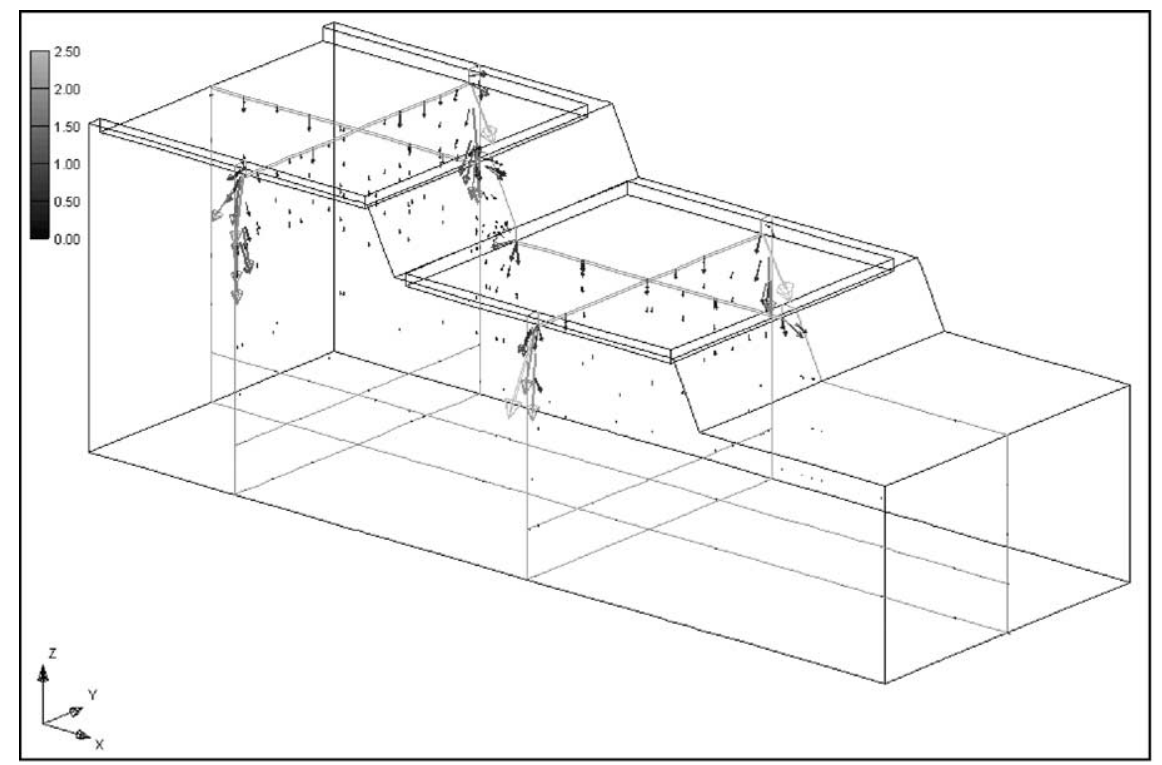

Fig. 9. Darcy velocity flow field for lateral seepage in the terraced paddy $\left(\mathrm{cm} \mathrm{d}^{-1}\right)$.

paddy and most of it vertically recharges to the shallow groundwater aquifer.

Although a drainage condition pertains over the last 25 days, the areal average percolation, the percolation through the bottom of the plow sole and the percolation below the soil bund (measured at the depth of the bottom of the plow sole), all increase with time (Fig. 8). The percolation of the plow sole increases from 0.48 to $0.68 \mathrm{~cm} \mathrm{~d}^{-1}$. The percolation below the soil bund increases from 0.48 to $1.24 \mathrm{~cm} \mathrm{~d}^{-1}$. The areal average percolation increases from 0.48 to $0.77 \mathrm{~cm} \mathrm{~d}^{-1}$. The distance traveled by

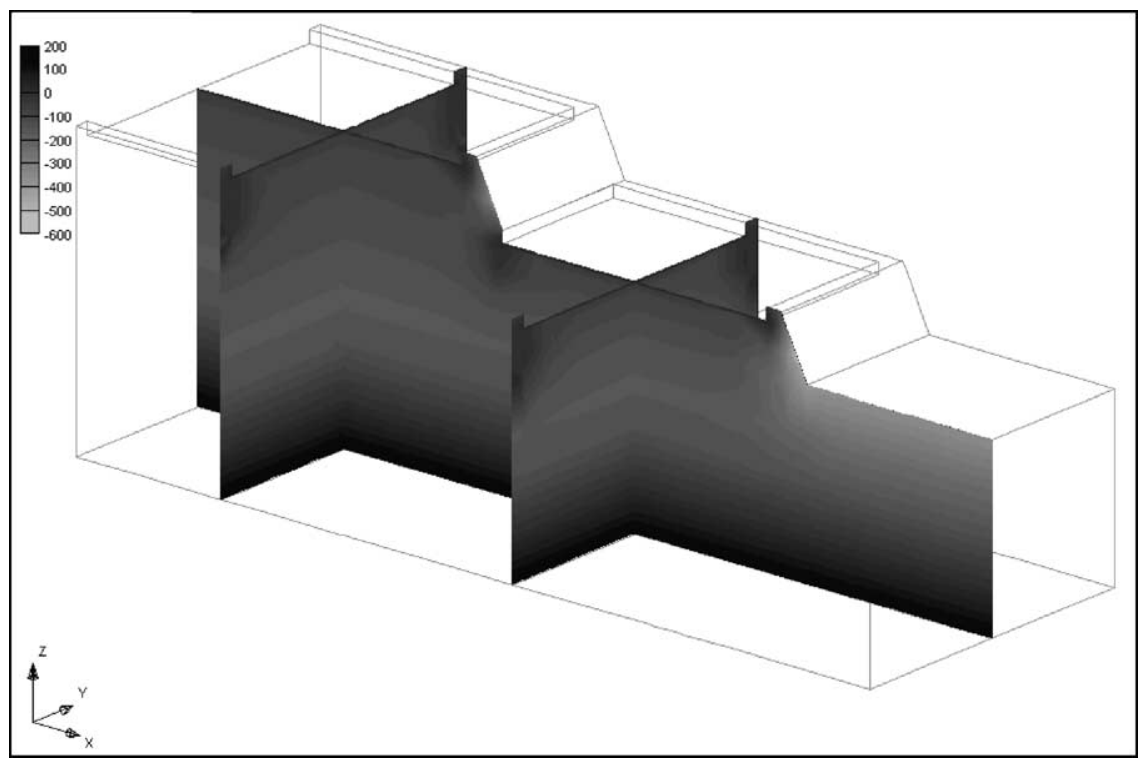

Fig. 10. Simulated pressure head distribution in the terraced paddy $(\mathrm{cm})$. 


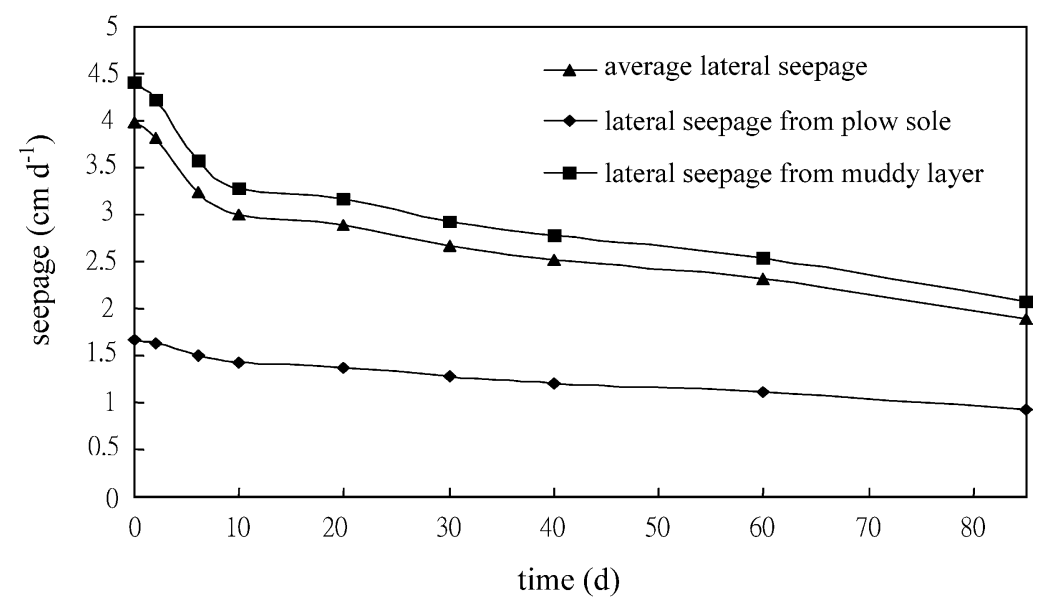

Fig. 11. Lateral seepage in the upstream terraced paddy of the soil bund.

the percolated water over the 25 days of drainage ranges from 12 to $19 \mathrm{~cm}$, which is within the muddy layer. A vertical hydraulic gradient is maintained in the plow sole, causing the percolation rate to increase continuously. A high percolation rate below the soil bund follows from the large hydraulic conductivity and high hydraulic gradient below the bund. Moreover, the parameter that primarily governs water percolation is the hydraulic conductivity of the plow sole.

Lateral seepage around the soil bund, without the plow sole underneath, develops in (1) the upstream and downstream bunds and moves downward, and (2) the toe of the downstream paddy and moves upward from the slope surface (Figs. 2 and 9).
Lateral seepage causes water to accumulate at the bottom of the bund, markedly increasing the pressure head and raising the water saturation well above that in the central paddy soil below the plow sole (Fig. 10).

The lateral seepage from the plow sole differs from that of the muddy layer. The initial lateral seepage from the plow sole to the soil bund declines from $1.67 \mathrm{~cm} \mathrm{~d}^{-1}$ to a final lateral seepage of $0.92 \mathrm{~cm} \mathrm{~d}^{-1}$, whereas the initial lateral seepage from the muddy layer to the soil bund falls from $4.41 \mathrm{~cm} \mathrm{~d}^{-1}$ to a final lateral seepage of $2.06 \mathrm{~cm} \mathrm{~d}^{-1}$. The average lateral seepage decreases from an initial value of $3.98 \mathrm{~cm} \mathrm{~d}^{-1}$ to a final value of $1.88 \mathrm{~cm} \mathrm{~d}^{-1}$; it is strongly governed by the lateral seepage from the muddy layer (Fig. 11). Fig. 12 plots lateral seepage in

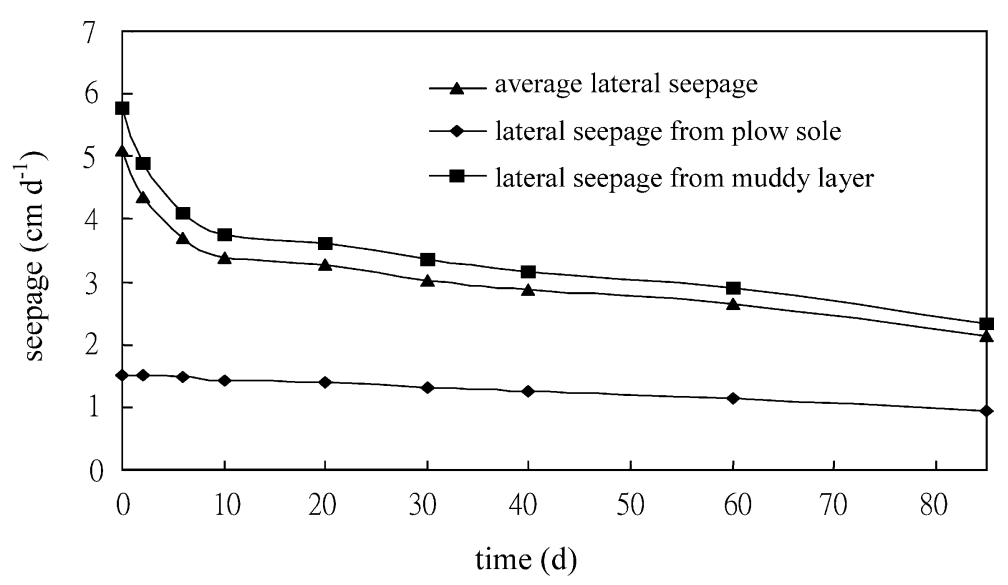

Fig. 12. Lateral seepage in the downstream terraced paddy along the upstream slope surface. 
the downstream paddy along the upstream slope surface. The initial lateral seepage from the plow sole is $-1.50 \mathrm{~cm} \mathrm{~d}^{-1}$ and decreases to a rate of $-0.94 \mathrm{~cm} \mathrm{~d}^{-1}$. The negative sign states that the lateral seepage is upward. The initial lateral seepage from the muddy layer to the upstream slope surface is $-5.77 \mathrm{~cm} \mathrm{~d}^{-1}$, falling to $-2.34 \mathrm{~cm} \mathrm{~d}^{-1}$. The average lateral seepage consequently decreases from -5.1 to $-2.12 \mathrm{~cm} \mathrm{~d}^{-1}$, and is also governed by the lateral seepage from the muddy layer with a difference in flow direction of upward movement of water along the slope surface. The downward and upward movement of water along the slope surface from the upstream and downstream fields results in unsaturated condition in the middle of the slope surface. The discontinuous water saturated conditions along the slope surface differ from those of the saturated seepage face. No water flow develops along the slope surface to supplement irrigation water for the downstream paddy. These findings are consistent with the water saturation measured in the terraced paddy fields.

\section{Conclusions}

This study investigates the percolation and seepage of water through paddy bunds in both flat and terraced paddies. The water saturation of various types of bund was measured to determine the characteristics of an unsaturated slope surface in a terraced paddy. A 3D groundwater model, FEMWATER, was then applied to simulate percolation and seepage along the bund, with and without a plow sole underneath. In the flat paddy, the percolation flux through the soil bund with plow sole underneath, was $0.4 \mathrm{~cm} \mathrm{~d}^{-1}$, whose value is similar to the water infiltration flux through the central paddy. However, when no plow sole was underneath the soil bund, then the percolation flux was $0.85 \mathrm{~cm} \mathrm{~d}^{-1}$ or double the water infiltration flux through the central paddy.

In the terraced paddy, the percolation of the central paddy is primarily vertically downward, whereas lateral seepage dominates the flow near the bund. The field near the bund is under a high hydraulic gradient. The simulated infiltration flux in the bund after an 85-day period of rice cultivation exceeds that in the central paddy by a factor of 2.72 . The simulated final percolation flux from the bund also exceeds the percolation flux from the plow sole by a factor of 1.82. The downward and upward lateral seepage fluxes from the bund along the slope surface are 2.01 and $-2.12 \mathrm{~cm} \mathrm{~d}^{-1}$, respectively. However, the lateral seepage flux does not fully saturate the surface of the hillside soil. The simulation clearly demonstrates that the water that seeps from the upstream paddy does not move to the downstream paddy but is reused as a subsurface return flow for irrigation. Both experimental and simulation results show the water movement mechanisms in the terraced paddy and confirm the presence of an unsaturated seepage face along the slope surface in the terrace field. Subsurface return flow is unlikely to develop in the slope surface. Most of the infiltrated water from the terraced paddy percolates and recharges to the shallow groundwater aquifer.

\section{Acknowledgements}

The authors would like to thank the Chi-Sheng Water Management Research and Development Foundation, the National Science Council and the Council of Agriculture of the Republic of China, for financially supporting this research under Contracts Nos. NSC-90-2313-B002-262 and 90 Nou Fa-2.2-Lin-08 (10).

\section{References}

Bouman, B.A.M., Wopereis, M.C.S., Kropff, M.J., ten Berge, H.F.M., Tuong, T.P., 1994. Water use efficiency of flooded rice fields. (II) Percolation and seepage losses. Agric. Water Mgmt. 26, 291-304.

Chen, S.K., Liu, C.W., 2002. Analysis of water movement in paddy rice fields. (I) Experimental studies. J. Hydrol. 260, 206-215.

Chen, S.K., Liu, C.W., Huang, H.C., 2002. Analysis of water movement in paddy rice fields. (II) Numerical simulations. J. Hydrol. 265, 259-271.

Engineering Computer Graphics Laboratory, 1996. Groundwater Modeling System Reference Manual, Brigham Young University, Provo, Utah.

Huang, H.C., Chen, S.K., Cheng, S.W., Liu, C.W., 2001. Numerical simulation of the subsurface flow field of riceterrace on hillside. J. Taiwan Water Conservancy 49 (1), 1-18.in Chinese.

Klute, A., Dirksen, C., 1986. Hydraulic conductivity and diffusivity: laboratory methods. In: Klute, A. (Ed.), Methods of Soil 
Analysis, second ed., American Society of Agronomy, Madison, pp. 687-734.

Lin, H.C., Richards, D.R., Yeh, G.T., Cheng, J.R., Cheng, H.P., Hones, N.L., 1997. FEMWATER: A Three Dimensional Finite Element Computer Model for Simulating Density Dependent Flow and Transport, in Varially Saturated Media. Report CHL-96-12, US Army Corps of Engineer, Vicksburg, MS.

Tuong, T.P., Wopereis, M.C.S., Marquez, J.A., Kropff, M.J., 1994. Mechanisms and control of percolation losses in irrigated puddle rice fields. Soil Sci. Soc. Am. J. 58, 1794-1803.
Walker, S.H., Rushton, K.R., 1984. Verification of lateral percolation losses from irrigated rice fields by a numerical model. J. Hydrol. 71, 335-351.

Wopereis, M.C.S., Wostem, J.H.M., Bouma, J., Woodhead, T., 1992. Hydraulic resistance in puddle rice soils: measurement and effects on water movement. Soil Tillage Res. 24, 199-209.

Wopereis, M.C.S., Bouman, B.A.M., Kroff, M.J., ten Berge, H.F.M., Maligaya, A.R., 1994. Water use efficiency of flooded rice fields. (I) Validation of the soil-water balance model SAWAH. Agric. Water Mgmt. 26, 291-304. 